\title{
10
}

\section{Nordic Legal Aid and 'Access to Justice' in Human Rights. A European Perspective}

\author{
Jon T. Johnsen
}

\section{Introduction}

This chapter identifies some important features of the welfare perspective in Nordic legal aid schemes and compares them to a major European perspective, namely the 'access to justice' ideology of human rights.

Legal schemes have many characteristics that can be used for comparison. One important aspect is the legal provisions that control access to legal aid. Another is the empirical dimension: To what extent does actual delivery correspond to the legal criteria? Since empirical data suitable for European comparisons are scarce, my focus is mainly on the normative issues. However, it seems safe to assume that applications for legal aid that fall outside the legal entitlements are unlikely to be covered. International human rights bring in an important legal dimension through their access to justice provisions, which also contain standards for legal aid schemes that states must fulfil.

J.T. Johnsen $(\bowtie)$

Department of Public and International Law, University of Oslo, Oslo, Norway 
The chapter starts with a brief introduction to the welfare perspective and the extent to which the different sectors delivering legal services also offer non-commercial legal aid to people of limited means. The analysis sticks to the schemes organised by the legal aid acts in Finland and Norway. The next part compares the main normative framework for access to legal aid, focusing on problem criteria and poverty criteria and discusses the welfare ideas behind the entitlement criteria of the schemes. The following part first outlines the main ideas about legal aid in the 'access to justice' ideology of human rights. Then it turns to the main features of European Court of Human Rights' (ECtHR) case law on legal aid, and compares it to the welfare ideology of Nordic legal aid on problem and person criteria. The Council of Europe (CoE) supplements the case law of ECtHR with soft law on legal aid, which is summarised in the next part. This part also describes the initiative of the $\mathrm{CoE}$ to build a new institution-namely the European Commission for the Efficiency of Justice (CEPEJ) — that works to improve access to justice in Europe and focuses on its efforts to fulfil the soft law expectations concerning legal aid. The final part adds an empirical dimension to the analysis by using European statistics gathered and developed by CEPEJ to provide some basic information about the present state of the existing legal aid schemes in Europe. It makes a more detailed comparison of budgets and cases between the Nordic schemes and the other Western European schemes spending the most per inhabitant. Finally, conclusions are drawn on how the Nordic schemes meet welfare challenges, their performance in a European perspective and whether human rights can become a driver for legal aid reform in Europe.

\section{Legal Aid Ideology in the Nordic Schemes}

Welfare systems are meant to support people when they experience health problems, poverty, or unemployment, and to provide them with education according to their capacities. Governments can help by organising and providing welfare services themselves-for example, through public hospitals and schools - and by economic support by, for example, buying services for the needy from private providers or refunding the costs of using them (Berg and Christiansen 2014). 
The Nordic countries have mainly put in place universal public schemes for health and education-including all groups in society-but have allowed supplementary private providers. However, the provision of some types of welfare services - like dentistry - is left mainly to the private sector. How do the legal aid schemes in the Northern countries conform to these ideas?

Nordic governments expect most people to buy the legal help they want in the legal services market. The main purpose of legal aid schemes is to provide people with legal services when they cannot otherwise afford to have their legal problems solved. Legal aid is meant to be a supplement to market delivery. Universal schemes have never been a realistic option for legal services.

In Nordic legal aid, we might distinguish between two main versions of legal services ideology (see Johnsen 1994, pp. 303-308; 2006, pp. 24-39).

Market ideology dates back to the end of autocracy and has been strongly supported by advocates and their organisations ever since. The modern version, as it has appeared in the legal aid debate since the 70 s, views legal services as consumer goods, similar to other types of consumer services that ought to be distributed through the mechanism of the market. Actual consumption depends on the economic resources and priorities of the individual. Establishing a public delivery system interferes with the market. What can be accepted is a subsidy that addresses the basic legal needs of the weakest groups. How efficient and how generous such a subsidy system ought to be is a matter of policy.

Welfare ideology, by contrast, originated from the political ideology of the organised labour movement, and became integrated into its welfare thinking. Because ordinary and poor people could not master the complexity of the welfare regulations and bureaucracy, and appeared unable to assert their rights successfully, welfare law became less effective for the groups that were most in need of it. Legal services schemes became vehicles to improve the efficiency of the welfare apparatus. If judicare schemes appeared inadequate, government had to organise a public system that could deliver the legal service needed (Johnsen 1994, pp. 307-308; 2006, p. 37). 


\section{Nordic Delivery Models}

The two dominant legal aid ideologies have impacted differently on the Nordic legal schemes. Delivery model alternatives to judicare appeared at the end of the nineteenth and beginning of the twentieth centuries. In all Nordic countries, voluntary legal clinics evolved, aimed at solving working class problems. When organised labour became a significant political power, these offices received public subsidies, and over time they became integral parts of the public legal services schemes. Salaried public offices were most significant in Sweden and Finland, and less so in Norway and Denmark. (Johnsen 1994, pp. 304-305).

In the remainder of the chapter, I limit my analysis to the schemes in Finland and Norway. Finland's legal aid is more different from Norway's than from the schemes in the other Nordic countries. Today, a nationwide network of public legal aid offices constitutes the backbone of Finnish legal aid, while Norway almost entirely relies on judicare (see Chaps. 2 and 4). By choosing the two extremes, we should also cover important features of the Danish and Swedish schemes.

We can distinguish between three main sectors of legal aid delivery in Finland and Norway (Johnsen 2008, 2009).

Commercial delivery or delivery for profit is the hallmark of the market sector. Law firms belong here. Market delivery, however, can be used in legal aid when paid for by someone other than the user. When governments pay all, or part of, the lawyers' costs, the expression 'judicare scheme' is commonly used.

Market delivery is perceived as a guarantee of lawyer independenceincluding in the field of legal aid. Lawyers are free to pick the commissions they want, without any loyalties to interests other than the client's, and potential clients are free to hire the lawyers they think best suited to the task. Lawyer independence-especially from government-has been a major argument in favour of judicare schemes put forward by advocates' associations. We might ask if insurance schemes that cover legal costs may also count as legal aid schemes. However, even if the user's costs are limited to the insurance premium, with an additional contribution to costs when the policy is used, insurance schemes are basically commercial 
enterprises. Companies offer such cover for profit. Nonetheless, the effects for the users are more or less to the same as judicare. Unions and other interest organisations often have similar schemes for covering legal costs for their members.

The public sector consists of public institutions that deliver legal services as one of their responsibilities. Governments do not buy legal services for the needy from private providers, but organise public offices and hire providers to staff them. Such entities can be law centres, public law offices, or defender offices; they may be integrated into welfare bureaucracy or other institutions of public administration, public corporations and foundations, public advice centres, ombudsmen etc. Such providers as public consumer offices, debt advisors, and student legal clinics can also be included in the public sector. These providers are usually salaried, which disconnects their economic interests from the cases they handle.

The third sector consists of an assortment of deliverers that do not fit into the two previous sectors. Their common characteristic is that they deliver non-commercial legal services to ordinary and poor people, and to vulnerable groups, as part of their activity. Examples are:

- Membership organisations - providers that are organisations within trade, labour, or other interest organisations that hire legal experts to advise their members on legal issues within the organisation's field of activity.

- Volunteer organisations_-especially those targeting deprived or vulnerable groups and including interest organisations, NGOs, grassroots organisations and charities. Like membership organisations, they may offer legal service schemes free of charge to their target groups.

Unlike the situation in common law countries, third sector legal aid has received limited attention in Nordic legal aid research, although some information exists. Norwegian policy reports on legal aid have sometimes described legal aid delivery by a number of third sector organisations. An extensive comparative project on legal aid in Finland and Norway also carried out a provisional mapping of third sector delivery (Johnsen 2008). ${ }^{1}$ 
Findings indicate that third sector schemes provide a huge share of the total supply of non-commercial legal services in both Finland and Norway. They cover a far larger volume of legal service needs than the Finnish and Norwegian Legal Aid Acts (FLAA, NLAA), and both countries allocate significant public funds to them. (Johnsen 2009, pp. 5-6, p. 18 and more extensively in Johnsen 2008, pp. 25-29, 77-78.) Due to the lack of data, I will focus my analysis on the state funded schemes established by the FLAA and NLAA, with a few detours into third sector schemes when substantiated. ${ }^{2}$

\section{Main Entitlement Criteria}

Two main types of criteria are commonly used in public legal aid schemes for delimiting people's access to services. Problem criteria identify the type of legal issues that are covered under the scheme, while poverty criteria identify the means limits set for applicants to qualify; and whether contributions are a condition for grants. My question is how far has welfare ideology impacted on these main criteria in Finnish and Norwegian legal aid? I will focus on civil schemes and briefly comment on criminal schemes when substantiated.

\section{Problem Criteria}

Finland uses general, discretionary criteria for identifying the problems that qualify for legal aid under the civil scheme. All legal problems may qualify for legal aid unless certain specified exceptions apply (FLAA section 1). Norway uses a different technique and specifies in considerable detail the types of problems that qualify for civil legal aid. The NLAA makes a major distinction between litigation aid and aid for other legal problems. The list contains 11 specific categories for legal assistance outside the courts, and 15 for legal representation before the courts and certain other judicial bodies (NLAA sections 11, 12, 17). Other categories of problems are excluded from legal aid unless the circumstances are exceptional. 
The Norwegian criteria focus on high frequency problems, without much evaluation of the individual welfare significance of the problem. Legal service needs, however, arise from problems with both high and low frequency in the population. A low frequency problem might also cause serious harm to the welfare of those affected (Johnsen 2008, pp. 42-43, Johnsen 2009, p. 9). The discretionary Finnish criteria provide markedly better possibilities for capturing all the different types of serious legal problems that exist in the target groups.

In a welfare perspective the Norwegian civil priorities show an urban bias. They focus on dissolution of marriage and cohabitation, compensation for personal injuries, loss of a breadwinner and criminal injuries, job dismissals, eviction, and complaints about denial of benefits. Family dissolution, living in rented accommodation, and working as an employee are far more common in urban areas than in rural ones, while legal problems connected with farming, fishing, forestry, and homeownership mainly fall outside the scheme. Several important minority problems are also outside the priorities of the NLAA.

Since the FLAA covers all sorts of legal problems, it overlaps both with the defender scheme and the victims' scheme, and with the third sector. Taken together, the criteria cover almost all serious welfare problems. On the other hand, the NLAA states that its schemes are subsidiary to other public and private schemes and only to be used if alternatives are lacking, NLAA section $5 .^{3}$ NLAA coverage is also less extensive. Although the third sector covers a varied selection of problems, it has not been harmonised with the NLAA schemes. This means that categories of problems exist that are not covered by any non-commercial scheme.

The main provisions for civil legal aid in Finland cover most legal problems that the target groups experience. Few serious problems are excluded. The Norwegian LAA scheme, by contrast, only includes selected parts of the legal problems people experience.

When it comes to criminal legal aid, the Norwegian defender scheme appears more liberal than the Finnish one, which depends on differences in the seriousness of the crime charged. In Norway, the use of a defender is obligatory and entitles the accused to legal aid whenever a criminal charge is decided in ordinary hearings, Norwegian Criminal Procedure Code (NCPC) section 96. In Finland, the minimum statutory penalty must be four months, Finnish Criminal Procedure Code (FCPC) Chap. 2. However, since the 
FLAA covers all sorts of legal problems, criminal offences are also included for people who satisfy the poverty criteria.

\section{Poverty Criteria}

Since, in both countries, the main vehicle for providing legal services to the population is the market, a major welfare idea behind the LAA schemes is to support those who lack the buying power necessary for using the market efficiently. Both countries therefore use complex economic criteria, or means tests, to identify the target population, which makes precise comparisons difficult (see Chaps. 2 and 4) for comprehensive descriptions.

Means testing is not merely a question of someone's ability to bear costs. Depending on their level of poverty, people might be able to pay the full cost of simple advice and a contribution to the cost of a lengthy trial.

The two countries use different economic limits for free legal aid and for legal aid with contributions. At first sight, the Norwegian overall limits are the more generous. They do, however, involve different ways of calculating people's assets. Estimates continue to indicate that the Finnish limits are significantly more generous for households of two or more people, while they are approximately equal for single people.

In both countries the ceilings for free legal services are approximately half the upper limits for legal services requiring a contribution. Finland charges a basic contribution of $70 €$ from everyone above the contribution limit. In addition, progressive contributions from $20-75 \%$ of the costs apply, depending on the grantee's income. Finland does not put any limit on their percentage contributions.

Norway does not require progressive contributions. Grantees above the contribution limit are charged a basic contribution of about $100 €$ for non-litigation aid and $25 \%$ of the costs for litigation aid. The maximum litigation contribution is $627 €$, irrespective of the actual costs. Although the ceilings for free legal services seem somewhat more generous in Finland than in Norway, Finnish contributions are significantly larger than those in Norway. 
Finland uses means testing almost without exception. Norway omits a narrow selection of civil cases from means testing, and grants legal aid irrespective of the applicant's income and assets. One exception is cases involving serious interventions by the government into people's integrity-for example, by involuntary hospitalisation for health reasons or public child custody. Another exception is cases resulting from serious intrusions by other citizens, like compensation to crime victims. No contributions are payable in such cases.

The justification for these exceptions is not poverty and the inability to carry the costs. In the case of governmental interventions, the idea is that, although justified, no one who suffers loss of freedom or other essential integrity intervention ought to pay for the legal costs they incur. Similarly, when someone is the victim of criminal acts that cause serious bodily or mental harm or suffering, they ought not to have to pay the costs for using legal means to gain redress and rehabilitation.

In both countries, the main rule for civil litigation is that the losing party must cover the costs of the counterpart. On the other hand, both countries also except costs to the counterpart from coverage by legal aid (FLAA section 4, NLAA section 22). Finnish research shows that this cost risk deters poor and middle income people from litigation, irrespective of the merits of their case (Litmala 2006, pp. 166-188).

\section{Welfare Ideology Behind the Finnish and Norwegian Schemes}

How do Finland and Norway justify the present entitlement criteria for governmental legal aid and to what extent do they build on welfare ideology? ${ }^{4}$

Both Finland and Norway have introduced constitutional provisions that grant their citizens access to the courts or other independent judicial organs with matters that concern their legal rights and duties. The Finnish constitution, section 21 (Amendment of 11.6.1999/731), guarantees the public access and information about the case handling, the right to argue the case, the right to a reasoned decision, and to appeal. Other guarantees 
of a fair trial and fair public administration should be laid down by law. The Norwegian constitution, section 95, mainly ensures access to a fair and public trial by an independent and impartial court within a reasonable time, without further explication (Amendment of 27.5.2014/778).

Both constitutions emphasise equality before the law as an essential principle for legal aid policy. No one should suffer from legal losses due to lack of personal abilities or financial resources. The Finnish provisions on the objectives of the legal aid schemes, however, more distinctly express the government's obligation to establish adequate delivery systems than do those of Norway.

The Finnish motivation for its present legal aid act arises from the law's increasing complexity and the fact that access to competent legal counselling is regarded as an important guarantee of access to justice and fair trials. Equality before the law is threatened by rising legal costs, and a fair and efficient judicial system cannot allow people to suffer unreasonable economic risks when protecting and enforcing their legal rights. In the end, it is a governmental responsibility to see to it that the constitutional principle on equal access to the courts becomes a reality (Regerings proposition 82/2001, p. 5.).

Finland's welfare model includes both litigation aid and legal help outside the courts. The entitlement to legal assistance comprehends all professional services deemed necessary to solve the problem-including a duty to ensure that the provider system is adequate. Although access to the courts is the main constitutional concern, the FLAA has significantly broader approach. What matters is the seriousness of the legal problem, not whether the courts are the right institution for problem solving.

Finland's network of public law offices provide everyone entitled to it with actual assistance. They serve as the entrance into the legal aid system by deciding all applications for legal aid. They are located according to both geographic and population criteria. They ensure a reasonably even distribution of legal aid capacity throughout the country (Johnsen 2009, p. 18). For court cases, an additional judicare scheme exists that grantees can use instead of the public law office. 
Such mechanisms are lacking in the Norwegian judicare schemes, although the motivation for the present schemes also emphasises equality before the law and the importance of legal services. Everyone ought to have access to the help they need, at an affordable price (Ot.prp. 35, pp. 36-38, St.meld. nr. 25, pp. 19-21, St.meld. nr. 26, p. 21).

Norway, however, has significantly more exceptions from this main principle than Finland. While the FLAA regards necessary legal aid as a citizen's right, its Norwegian counterpart defines access to legal aid as a welfare benefit restricted to legal problems of great personal or welfare importance to the applicant. Norway's focus on civil legal aid is more limited to access to the courts, and the government's obligation to provide legal services is mainly limited to the funding necessary to hire a lawyer in private practice. In most types of civil case, it is left to the grantee to find a lawyer willing to handle the case for the public fee.

The differences between Finland and Norway in their general approach to legal aid policy are marked. The welfare model dominates the government schemes in Finland, while Norway mainly uses judicare.

In Norway, welfare ideology is used to prioritise a limited range of problems as the 'most important' within a restrictive frame. Resources are spent on a universal scheme giving everyone legal aid without costs in particular cases, without asking if they can carry the costs themselves. The underlying idea differs from the welfare ideology behind legal aid that aims to help people who lack sufficient resources to obtain the legal services they need.

A policy that expands the cover for the poor and deprived better accords with the welfare ideology's aim of securing equal access to the justice system for all. For this, cover needs to be extended according to the Finnish problem criteria to all that qualify according to the poverty criteria, before limited resources are spent on more affluent groups. However, gaining political support for selective schemes that prioritise support to the poor is significantly more difficult than getting support for universal schemes, even when they become more costly. We can see the Norwegian model as a compromise between these two welfare ideologies. 


\section{The European Court of Human Rights' Case Law on 'Access to Justice"}

Human rights include norms that provide legal protection for everyoneusually expressed in the concept of 'access to justice'. The right to legal aid is triggered when the individual lacks resources to pay for necessary legal services and this could be perceived as a European competitor to the Nordic welfare ideology. We shall explore how these two ideologies interact in legal aid. Before I make the comparison, I will outline the main human rights perspective on legal aid.

\section{Main Features of the 'Access to Justice' Perspective}

In the human rights context, 'access to justice' is perceived as a broad label with some ambiguity. Francesco Francioni distinguishes between three meanings:

Generally the concept is used to 'signify the possibility for the individual to bring a claim before a court and have a court adjudicate it'. A narrower meaning is 'to have his or her case heard and adjudicated in accordance with substantive standards of fairness and justice.' A third and even more specialised meaning is that 'access to justice can be used to describe the legal aid for the needy, in the absence of which judicial remedies would be available to those who dispose of the financial resources necessary to meet the, often prohibitive, costs of lawyers and the administration of justice' (Francioni 2007, p. 1).

In the human rights setting, legal aid is perceived as one of several vehicles for access to justice. It is part of a broader rule of law and access to justice obligation for governments. Others include accessible courts, simple procedures, alternative disoute resolution (ADR), conflict prevention measures, such as legal planning, educational measures to ensure that people themselves are legally competent, etc.

My analysis focuses especially on the legal aid element in the broad obligation, which is well expressed in the third of Francioni's definitions. When we try to elucidate its significance, however, the wider context should be kept in mind. The different policy measures available for 
promoting access to justice are to some degree interchangeable and the human rights obligations therefore have similar flexibility.

Globally, the UN Convention on Civil and Political Rights (CCPR) article 14 is the main provision for access to justice today and the UN is the main organisation for implementing it (International Covenant on Civil and Political Rights 1966). In Europe, the major provision for access to justice is the European Convention on Human Rights (ECHR) article 6, with the Council of Europe $(\mathrm{CoE})$ as the prime promoter of the convention (European Convention of Human Rights and Fundamental Freedoms 1950). Since all member states of the $\mathrm{CoE}$ have also ratified the CCPR, ${ }^{5}$ both Finland and Norway are obliged to enforce both CCPR, article 14, and ECHR, article 6, and Norway has also made them a part of domestic law that outranks national legislation (Menneskerettsloven 1999 sections 2 and 3).

Our focus is the European perspective. I shall concentrate on the $\mathrm{CoE}$ and the legal aid provisions of the ECHR. The $\mathrm{CoE}$ uses two major instruments in implementing them, namely the European Court of Human Rights (ECtHR) and the European Commission for the Efficiency of Justice (CEPEJ). Together with the European states, they form the most extensive enforcement system for 'access to justice' in the world.

\section{The Obligation to Provide Legal Aid}

Article 14 (1) of the CCPR and article 6 (1) of the ECHR entitle everyone to a fair hearing in both criminal and civil cases. An accused person is explicitly entitled to legal aid 'where the interests of justice so require' as a 'minimum guarantee'. The wording appears discretionary and leaves many issues open to interpretation.

Since the articles demand fair trials for both criminal charges and other 'suits of law', the 'interests of justice'-standard for legal aid cannot be limited to criminal cases. They must be understood as specifications of the general principle of the right to a fair trial. States must also provide legal aid in civil cases, when it is deemed necessary to make the right to a fair trial effective. 
The wording of ECHR article 6 only covers 'civil rights and obligations' and 'criminal charges'. It does not mention rights and duties regulated by administrative law. However, the ECtHR has gradually expanded the scope of article 6. CCPR article 14 will anyhow oblige European governments to provide legal aid in all 'suits at law' irrespective of the type of law involved.

The entitlement to legal aid has been brought before the ECtHR in a number of cases. I will comment on three that relate to the problem and person criteria, because they contain important requirements for national legal aid schemes. Airy $v$ Ireland, of 1979, relates to civil legal aid, but has a bearing on criminal aid too (Application No. 6289/73). Airy was a lowpaid worker and a homemaker with four children; at times, she was on unemployment benefit. She wanted a judicial separation from her husband, only obtainable at the Irish High Court, but could not afford to pay for legal representation. Legal aid was not available. The ECtHR accepted that self-representation in the High Court would not be effective, due to the character of the substantive matter, the complexity of the proceedings and Airy's personal capacity. ( $\$ 20-28)$.

The decision set the precedent, which obliges governments to provide sufficient funding for legal aid according to the following discretionary criteria:

- importance of the case to the individual (applicant);

- complexity of the case and the individual's capacity to represent himself;

- costs and the individual's capacity to carry them.

The Airy principles have been confirmed in several judgements. A violation will be established by ECtHR if costs act as an actual barrier to access to court.

The Airy criteria of the ECtHR do not distinguish between different types of legal claims. Some states_like Norway-limit the scope of their schemes either by excluding certain types of legal problems, or by restricting them to selected categories. According to article 6, legal aid must be provided 'when the interests of justice so require'. We might therefore ask if this minimum requirement is compatible with restrictions on the types of problems that are covered. The main criterion is the problem's 
importance to the individual, not the legal category. The ECtHR decision in Steel and Morris v UK, of 2005, further develops the Airy principles (Application No. 64186/0):

Steel—a part-time bar worker-and Morris—a postal worker-had joined London Greenpeace (unconnected with Greenpeace International), a small group promoting environmental issues. The group published a leaflet accusing McDonald's of contributing to 'the starvation of the third world' by 'hungering' for profit, economic imperialism, gross misuse of resources, destroying rainforests, producing unhealthy food using a lot of chemicals, exploiting children as consumers, inhuman slaughtering of animals used in hamburger production, and exploiting young unskilled workers as staff. McDonald's sued the applicants for slander.

The proceedings became one of the most extensive in English history. The judgments alone filled more than 1100 pages $(\$ 65)$. Although the applicants fulfilled the means test, defamation proceedings were outside of the problem criteria of the legal aid scheme in England. They were effectively left to represent themselves, while McDonald's used a team of experienced lawyers. $(\$ 58,68)$.

ECtHR found that in a matter of such complexity, neither the sporadic help from volunteer lawyers nor extensive assistance from the judge, could form 'any substitute for competent and sustained representation by an experienced lawyer familiar with the case and with the law of libel ...' The disparity between the levels of representation 'was of such a degree that it could not have failed ... to have given rise to unfairness, despite the best efforts of the judges at first instance and on appeal' ( $\$ 69)$. The Court concluded that the denial of legal aid was a violation of ECHR Article $6(1)(\$ 72)$. The UK argued in vain that 'states did not have unlimited resources to fund legal aid systems, and imposing restrictions on eligibility for legal aid in certain types of low priority civil cases was therefore legitimate, if such restrictions were not arbitrary' ( $\$ 53)$. The Court accepted that a defamation action might generally be of lesser importance to vital personal interests than a claim for legal separation, as in Airy. However, defamation issues had to be considered according to the Airy criteria too. Therefore, legal aid schemes cannot exempt selected categories of problems from legal aid irrespective of their importance to the individual. 
The 'access to justice'-approach to legal aid focuses on access to courts and similar judicial institutions. The human rights obligations on governments to provide legal aid are therefore mainly limited to what is necessary for proper enjoyment of them. To what extent do human rights oblige states to provide legal assistance outside the courts?

Many disputes that end in court might well have been resolved in other ways, had the parties had access to legal advice at an early stage, be it by abandoning the claim, settlement, conciliation, mediation, arbitration, etc. We also know that effective use of the right to a fair trial presupposes that the decision on whether to go to court is an informed one. Most people need expert advice on whether to sue, or dispute a claim in court.

In Golder $v U K$ (Series $A$ No. 18, 1975), a prisoner wanted legal advice on whether to sue a guard for defamation. The prison would not allow him to write to a lawyer. The majority of the ECtHR stated that entitlement to a fair trial also included the right to make an informed decision on whether or not to use this entitlement. If a person lacks sufficient means for necessary counselling, legal aid might become a prerequisite for effective access to the court. However, since the main aim of Article 6 is to restrict access to court to claims with merits, governments' obligation to provide access to pre-trial legal counselling might be shaped to achieve this end.

To sum up, states can ensure access to justice for their citizens by various means. ${ }^{6}$ The practical impacts of governments' human rights obligation to provide legal aid therefore depend on the structure of their judicial systems. If one state-such as Ireland-practises complex and restrictive rules for divorce that demand that the irreversible breakdown of the marriage is established, and if divorces are available only through complex court proceedings, then the individual need for legal aid can be considerable among poor people who want to divorce. If other states-such as Finland and Norway-have no-fault divorce based on the request of one of the parties, and process divorce administratively, then brief legal advice might suffice in most cases. Liberal states, however, might see far more divorces than do restrictive ones, and might have to establish schemes capable of handling such cases for large numbers of people. 
Access also must work in practice. The ECtHR judgments therefore contain important requirements for national legal aid schemes. The wording of neither the ECHR nor the CCPR allows for any leeway for the member states if they deviate from the when the interests of justice so require'-standard by adopting inadequate legal aid schemes. The ECtHR has repeatedly said 'Article 6 (1) of the Convention imposes on the Contracting States the duty to organize their judicial systems so that they can meet its requirements. ${ }^{17}$ States cannot set priorities that conflict with the case law of ECtHR.

Access to the courts is meant to be effective for all citizens, irrespective of the type of legal problem, or of their economic situation. However, the ECtHR applies the Airy criteria to the actual circumstances of the complaint. Violations are always established in relation to individuals; systems are not considered as such.

The following will estimate the potential for violations, not actual breaches. The ascertainment of actual violation presupposes a complaint, and most violations are, for many reasons, never forwarded to the ECtHR. I will ask to what extent the present schemes in Finland and Norway are organised in such a way that violations are avoided. I will end with some reflections on how far the Nordic welfare models correspond to 'access to justice' and how far the market model and the welfare model on one hand, and the 'access to justice' model on the other, have impacted on each other.

\section{Comparisons to Nordic Legal Aid}

Since the main provisions for civil legal aid in Finland cover most legal problems that the target groups experience, I think the scheme conforms well to the Airy's problem criteria. All types of problems that have a certain degree of seriousness will qualify. Norwegian problem criteria seem far more problematic. They only include selected areas of need for services. The 'when justice so requires'-standard demands an individual assessment of the particular circumstances of each case-including low or non-priority problem areas. It follows from Steel and Morris that states cannot totally exclude certain categories of problems in the way Norway does. 
The Finnish criminal scheme included in the criminal procedure code appears significantly more restrictive than its Norwegian counterpart. I am not very familiar with the Finnish criminal code, but I would suspect that using a minimum statutory punishment of four months as the main criterion will open the way to quite severe punishment being imposed in the absence of a defender, which seems problematic viewed in the light of the Airy criteria. However, access to a defender when the accused also is covered by the FLAA seems comparable to that in Norway, since the FLAA supplements the defender scheme in the Finnish criminal procedure code. However, the exceptions in the Norwegian scheme might also conflict with the Airy criteria under certain circumstances.

The economic ceilings are fixed sums in both countries, which mean that the poverty criteria vary with inflation and general shifts in household economies, unless they are updated. Both countries have been unwilling to use automatic adjustment techniques_-such as those used for social insurance and pension schemes-to ensure that the poverty criterion is kept reasonably stable. Adjustments thus depend on policy considerations.

The 'access to justice' principle, however, relates to the actual costs in a particular case. The ECtHR asks if they constitute an unjust barrier to litigation. If they do, public subsidies are justified to the extent necessary to remove the barrier. Legal aid cannot therefore be limited to the poor. If costs become exorbitant, as in Steel and Morris, middle-income and even high-income people might also be in need of public support.

For people of some means, the human rights consequence is-as spelled out in Steel and Morris - that they can claim access to legal aid if trial costs exceed what they can reasonably be expected to pay. Human rights do not lay down a right to free trials, but costs must be adjusted to the economic capacity of the individual. A legal aid system that demands that middle-income people pay affordable legal aid costs themselves will not conflict with human rights if this protects against exorbitant costs. For the better-off, contributions might therefore be significant. However, since both Norway and Finland have upper income limits for cover, their schemes do not fully conform to human rights requirements.

Similarly, schemes that use percentage contributions without any ceiling, might also conflict with Article 6 if costs become high. In Steel and 
Morris even a $10 \%$ contribution to the costs would probably have ruined both applicants. Norway sets a limit of $627 €$ on its current percentage contribution requirements, while in Finland there is no upper ceiling.

Norway also exempts certain types of cases involving loss of freedom and redress for victims of criminal acts from both all means testing and all contributions. In these case categories everyone has free access to the courts, which obviously does not conflict with Steel and Morris. Finland, on the other hand, has income limits and levies contributions in these categories too.

If a court orders a legal aid grantee to pay the litigation costs of the other party, they are not covered by legal aid, neither in Finland nor in Norway. Therefore, the economic consequences of going to court can become unpredictable. The total costs for the individual should be reasonable. Access to justice should not expose people to cost risks that make it possible for wealthy and ruthless opponents to intimidate poor litigants by threatening to ruin them.

Although England does not award costs to the winning party, I think Steel and Morris has a bearing on this issue too. The ECtHR pointed to the size of the damages claim and said it would have ruined both Steel and Morris. Since McDonald's trial costs were estimated to be more than $£ 10$ million, if Steel and Morris had had to pay them it would have been devastating for them. It seems a safe inference that the ECtHR will include trial costs when it considers governments' obligation to guarantee access to justice. ${ }^{8}$

It seems that keeping the costs of the opposing party outside legal aid schemes amounts to a contradiction. If contributions are set on the basis of the costs that it seems reasonable to expect the grantee to bear, additional costs are bound to cause unreasonable harm. Rules that oblige a losing party to also pay the costs of the winner should be taken into account when the individual's need for legal aid to bear trial costs is considered. Neither of the two schemes fulfils such demands at present.

The 'access to justice'-approach to legal aid focuses on access to the courts and similar judicial institutions. The human rights obligations for governments to provide legal aid is therefore mainly limited to what is necessary for proper enjoyment of these rights. Providing legal aid outside the courts is mainly left to national policies. However, when legal 
assistance appears necessary for an informed decision on whether to use the courts, the 'access to justice'-obligation might mean governments have to provide pretrial aid. The problem criteria in the Finnish legal aid act apply to all sorts of legal problems, whether civil or criminal, or whether relating to court cases or to problems outside court. I therefore think the problem criteria in the Finnish scheme fulfil the human rights demands for pretrial legal aid.

As mentioned, Norway has separate problem criteria for civil legal aid in court cases and those in other cases, although the two generally overlap. Problems that fall outside the defined categories are generally not covered, which might conflict with the human rights demands, including at the pretrial stage.

The defender schemes in the criminal procedure codes in both countries mainly cover preparation and representation at the trial stage. They do not generally include assistance when the case is under investigation by the police or prosecution unless the suspect is in custody. Unlike its Finnish counterpart, the Norwegian legal aid act does not supplement the defender scheme either at the trial or at the pretrial stage. The deficits in the poverty criteria also apply at the pretrial stage in both Finland and Norway. It is, however, less probable that pretrial costs will become exorbitant.

To sum up, the main human rights provisions on access to justice appear in both the Finnish and the Norwegian constitutions. Entitlement in both countries more or less satisfies the access to justice demand, but does not fully correspond to the demands that follow from the case law of the ECtHR. The Finnish problem criteria seem well in line with the human rights demands, including those for pretrial aid, while the Norwegian schemes exclude important welfare problems from coverage, both at the pretrial and trial stage. Poverty criteria are most generous in Norway. However, none of the schemes cover costly civil trials for the more affluent part of the population-not even when costs become exorbitant. Neither do they cover trial costs awarded to the other party that the court obliges the grantee to pay.

We might note some differences between welfare ideology and access to justice. Human rights protect every human being, whether rich or poor. Welfare benefits are mainly limited to the poorer part of the population, 
unless the scheme is universal, which legal aid is not in any Nordic country, except for a few case categories in Norway.

As we can see from the differences between Finland and Norway, welfare ideology might be used to justify both a narrow delimitation of problems covered under the scheme, as in Norway, or a broad approach covering virtually any legal problem with potentially serious consequences, as in Finland. On the other hand, welfare ideology has resulted in legal assistance schemes for non-court problems in both countries with legal delimitations similar to the schemes for trials, which fall outside the access to justice demands.

\section{The European Commission for the Efficiency of Justice (CEPEJ): A New Instrument for Improving Legal Aid?}

\section{The CoE's Soft Law on Legal Aid}

The ECtHR's case law constitutes the minimum rights that governments must not violate. States are, however, free to establish better systems, and the $\mathrm{CoE}$ often encourages such developments by issuing resolutions and recommendations calling on governments to develop legal aid schemes. They are meant as political incentives to improve human rights, not as binding obligations. If member states adhere to them in practice, over the years they can become part of customary law or be included in the treaty through amendments and dynamic interpretations. Taken together they constitute a very ambitious programme for developing legal aid in Europe, and I will now summarise their main contents:

The CoE recommends that governments of member states should grant legal aid to all their citizens, and to all residents, on an equal footing with citizens (Resolution 76 (5) on legal aid in civil, commercial, and administrative matters 1976).

Economic obstacles to legal proceedings ought to be eliminated, and an appropriate system of legal aid will contribute to such aim. Access to legal advice for the economically weak is also important in the elimination of 
barriers to access to justice. The resolution has an appendix spelling out the principles for the means test and contribution system, the merits test, availability, the sort of legal services a proper legal aid system ought to deliver, and a complaint system; it says the financial responsibility for this should be borne by governments (Resolution 78 (8) on legal aid and advice 1978).

Governments should promote action to make the legal profession aware of the problems of the very poor, should promote legal advice services for them, carry the costs, and set up advice centres in underprivileged areas. States should facilitate access to ADR for the very poor, and extend legal aid to such methods of conflict solution. They should also extend legal aid for the very poor to all judicial bodies and proceedings, be they civil, criminal, commercial, administrative, or welfare, and give aid to aliens and stateless people resident in the territory of the member state in which the proceedings take place. Legal aid before judicial bodies should be refused only because claims appear inadmissible or manifestly ill founded, or because the application does not satisfy the standard of being 'in the interests of justice'. States are advised to simplify their procedures for granting legal aid to the very poor, and to consider enabling NGOs to provide representation before both national tribunals and international judicial bodies such as the European Commission and the ECtHR (Recommendation No R (93) 1 on effective access to the law and to justice for the very poor 1993).

States should encourage lawyers to provide legal services to economically disadvantaged people, and ensure that effective legal services are available to them, particularly if they are deprived of their liberty (Recommendation 21 on the freedom of exercise of the profession of lawyers 2000).

Governments should provide the text of the law, both as enacted and as consolidated, in an electronic form readily available to the public. Simple text access to the law database should be free of charge for the public, and governments should make the electronic base available to the private sector for further adaptation and dissemination (Recommendation 3 on the delivery of court and other legal services to the citizen through the use of new technologies 2001). 
The resolutions and recommendations adopted by the committee of ministers show that legal aid has been a matter of concern for the $\mathrm{CoE}$ for many years, and that European governments have received ample encouragement to develop their schemes.

However, 'access to justice' —including legal aid—increasingly became a challenge to the $\mathrm{CoE}$. Recommendations and resolutions did not appear sufficient, and the $\mathrm{CoE}$ recognised the need for a general overhaul of the judicial systems of the member states to ensure that they worked in accordance with both the Court's interpretations of the ECHR, and the CoE's soft law. To carry out the task, the CoE established the European Commission for the Efficiency of Justice (CEPEJ) in 2002.

\section{The CEPEJ's Main Challenges Concerning Legal Aid}

The CEPEJ became operational in 2003 as a human rights body specifically designed to improve access to justice in Europe (Resolution 12 establishing the European Commission for the efficiency of justice 2002). It is governed by a plenary with representatives from all member states that meet twice a year.

The CEPEJ focuses solely on policy-making arising from the 'access to justice' provisions in ECHR - especially article 6 . It is probably the only human rights body in the world today that has access to justice as its prime and only concern. The CoE especially sought improvements in legal aid, for both civil and criminal cases, and at both the pretrial and trial stage (Resolution (2002) 12 I.1.i.). Obviously the CoE's soft law on legal aid constituted an important platform for the CEPEJ's work.

Pursuant to the resolution, CEPEJ should develop indicators, collect and analyse data, and define measures and means of evaluation. It might also produce statistical reports, best practice surveys, guidelines and action plans, and collect opinions and general comments, to improve access to justice. The CoE encouraged the CEPEJ to collaborate with research groups and invite qualified people, specialists, and NGOs to take part in exchanges, and to arrange hearings and create networks of professionals working in the justice area (Resolution 12 (2002) article 
2 and 3 CEPEJ/GENERAL 2003, pp. 5-6). A great variety of tools was recommended for legal aid analysis and other access to justice purposes.

Improvements require voluntary acceptance and collaboration from the member states. The main task is to produce viable reform ideas, communicate them to governments, interest groups and the public, and assume that the states will adopt them voluntarily. In accordance with human rights thinking, the CEPEJ is a vehicle for general improvements in access to justice, and one that has legal aid schemes as a distinct part of its mandate. Such a broad range of policy commitments has the potential to produce far-reaching and innovative reforms for legal aid.

Yet legal aid has not been a priority in later CEPEJ programmes, and, although the potential of CEPEJ for an activist role in developing European legal aid seems significant, it has remained mainly unused so far.

Nonetheless, the judicial statistics of the CEPEJ do include legal aid. The methodological challenges are, or course, considerable, and the reliability of some statistics might be questioned, see CEPEJ EVAL (2014), pp. 6-12 for a description of the design of the study. However, I still think the data show significant differences between legal aid schemes in Europe.

Although rudimentary, they have improved over the years, and I will devote the next part of my chapter to analysing the main findings on legal aid in Europe.

\section{What Does the European Judicial Survey Tell Us About the Performance of European Legal Aid?}

In the following, I will give a brief overview of some findings, then I will make a more thorough — although not very sophisticated-comparison between the Nordic schemes and other European schemes that, judged by their cost, are among the top 25\% of the existing schemes in Europe. 


\section{The Overall Picture}

All 45 of the 47 members (Lichtenstein and San Marino are missing) stated that they provide legal representation in both criminal and civil court cases (CEPEJ EVAL 2014, 8 and Table 3.1, p. 70). They do not tell how extensive the provision was. (CEPEJ EVAL 2014, Q 16 and Q 21, pp. 488-481).

Legal aid expenditure also varied enormously among the states that could provide figures. While Azerbaijan spent $0.05 €$ and Hungary 0.09 $€$ per inhabitant, Germany spent $4.3 €$ and France $5.6 €$. At the top we find Northern Ireland with $50.7 €$ and Norway with $53.6 €$ (CEPEJ EVAL 2014, Fig. 3.4, p. 76) -more than ten thousand times the expenditure per inhabitant in Azerbaijan, and more than ten times the expenditure in Germany.

A listing of the total 2012 public expenditure on courts also shows huge variations. The republic of Moldovia spent the least, with $2.7 €$ per inhabitant, Azerbaijan 6.4€ and Hungary 32.9€. The figure for Northern Ireland was $40.5 €$ and for Norway it was $46.3 €$, while Germany spent $103.5 €$. The largest spender was Switzerland, with $122.1 €$. Data was given by 37 countries. (CEPEJ EVAL 2014, Fig. 2.5, p. 31).

These findings show that states have very different priorities as regards court and legal aid costs. In most countries, the legal aid budget made up only a very small share of the court budget, while Norway and the three UK jurisdictions, Northern Ireland, England and Wales, and Scotland spent more on legal aid than on courts.' Spending per inhabitant on courts by jurisdictions in Southern and South Eastern Europe, which seemingly have the greatest problems with speed and backlogs, is not very different from that of the Northern and Western European jurisdictions, but they spend comparatively very little on legal aid (CEPEJ EVAL 2014 Fig. 2.5, p. 31 and Fig. 2.15, p. 47).

The number of legal aid grants also varies significantly. Azerbaijan provided 6.5 grants per 10,000 inhabitants and Armenia 10.9, while Finland reported 144, Northern Ireland 314 and the Netherlands 326. (CEPEJ EVAL 2014, Table 3.5, p. 77). ${ }^{10}$ The Netherlands gave 50 times as many grants per 10,000 inhabitants as Azerbaijan did. 


\section{Nordic Legal Aid in the European Setting}

When we compare the legal aid expenditure of the Nordic states with that of other European states, both all the Nordic states end up in the top $25 \%$. All the other states in the top quarter are located in Northern and Western Europe too.

Table 10.1 shows the legal aid budget:

Norway is the biggest legal aid spender in Europe, followed by the Northern Ireland. There is a significant gap between these countries and the other Nordic states. Norway spends twice as much as Sweden per inhabitant, three times as much as Denmark, and four times as much as Finland.

The English-speaking countries, or 'common law' countries, constitute the group with the largest budgets in Europe, with the Nordic countries in second place. The Netherlands and Switzerland also are among the countries with the highest budgets per capita (Table 10.2).

Even states that spend the most on legal aid seem reluctant to report data that can be used to further analyse the huge differences in costs and provision. The picture for the rest of Europe is similar. Only 26 of 46 countries have provided one figure or more.

Still, we can see that the Netherlands handles three times as many court cases per 10,000 inhabitants as Norway, at a cost per case of only

Table 10.1 Legal aid budget per inhabitant, from the top 11 countries, in 2012

\begin{tabular}{ll}
\hline Country/ranking & Budget per inhabitant $(€) 2012$ \\
\hline 1 Norway & $53 \cdot 6$ \\
2 Northern Ireland & $50 \cdot 7$ \\
3 England and Wales & $41 \cdot 2$ \\
4 Scotland & $33 \cdot 7$ \\
5 Netherlands & $28 \cdot 8$ \\
6 Sweden & $24 \cdot 8$ \\
7 Ireland & $18 \cdot 1$ \\
8 Denmark & $14 \cdot 9$ \\
9 Switzerland & $13 \cdot 5$ \\
10 Finland & $12 \cdot 5$ \\
11 Iceland & $11 \cdot 1$ \\
\hline
\end{tabular}

44 of the 47 states gave data. Table 1 contains the top $25 \%$ of the 44 CEPEJ EVAL (2014) Fig. 3.4 p. 76 
Table 10.2 Legal aid cases and costs per case

\begin{tabular}{|c|c|c|c|c|}
\hline Country/ranking & $\begin{array}{l}\text { Court cases per } \\
10,000 \\
\text { inhabitants. }\end{array}$ & $\begin{array}{l}\text { All cases per } \\
10,000 \\
\text { inhabitants. }\end{array}$ & $\begin{array}{l}\text { Costs per } \\
\text { legal aid } \\
\text { case. } \\
\text { Court } \\
\text { cases. }(€)\end{array}$ & $\begin{array}{l}\text { Costs per } \\
\text { legal aid } \\
\text { case. All } \\
\text { cases. (€) }\end{array}$ \\
\hline 1 Norway & $90 \cdot 4$ & $128 \cdot 1$ & 5639 & 4180 \\
\hline $\begin{array}{l}2 \text { Northern } \\
\text { Ireland }\end{array}$ & $314 \cdot 8$ & - & - & - \\
\hline $\begin{array}{l}3 \text { England and } \\
\text { Wales }\end{array}$ & $125 \cdot 3$ & - & - & - \\
\hline 5 Netherlands & 290 & $326 \cdot 0$ & 863 & - \\
\hline 7 Ireland & $131 \cdot 9$ & - & 1373 & - \\
\hline 10 Finland & $79 \cdot 7$ & $143 \cdot 8$ & 887 & - \\
\hline
\end{tabular}

No figures: 4 Scotland, 6 Sweden, 8 Denmark, 9 Switzerland, 11 Iceland. Ranking from Table 10.1. States that did not give any of the four figures asked for, have been left out

CEPEJ EVAL 2014 Table 3.5 p. 77

$15 \%$ of Norway's. Finland's cost per court case is similar to that of the Netherlands, while Ireland's cost per case is $24 \%$ of Norway's.

The 2008 comparative study of Finland and Norway found that Norway spent more than twice as much per case on civil legal aid outside the courts (1000 € as against $425 €$ ) and more than three times as much per court case as Finland ( $4750 €$ as against $1500 €$ ). The average time spent on non-court cases in Finnish legal aid offices was estimated at 4-5 hours, and 9 hours in Norway. Time spent on civil court cases handled by private lawyers in Finland was estimated at 10 hours, compared with 50 hours in Norway, and the average time spent on court cases in the Finnish public legal aid offices was even lower (Johnsen 2009, p. 17).

Some of the differences might be explained by differences in case structure-especially the significant number of cost-free categories of legal aid cases in Norway - and by differences in the fees charged by private lawyers, and also by the somewhat lower time costs in the Finnish public legal aid offices. The major explanation, however, seems to be that most comparable categories of cases are dealt with faster and more economically in Finland than in Norway (Johnsen 2009, p. 17). The strong element of public legal aid offices in Finland's legal aid seems a major 
factor influencing judicare lawyers' time use since the public lawyers solve legal aid cases significantly faster than the judicare lawyers (Johnsen 2008, pp. 94-95).

\section{The CEPEJ's Evaluation of European Legal Aid Schemes}

CEPEJ EVAL (2014) also evaluates some of its findings about legal aid. The report welcomes the fact that:

'(A) all the member states provide legal aid both in criminal law and civil law fields, which is welcome when considering the requirements and the spirit of the European Convention on Human Rights and of the case law of the Court.' The report remarks that '[O]utside the criminal law field, legal aid can be granted more or less according to the type of case concerned.' (CEPEJ EVAL 2014, p. 88)

We read that the report does not set out to give a precise evaluation of the fulfilment of the problem criteria in the ECHR and the case law of the ECtHR from the data gathered. Person criteria are not mentioned at all. The CEPEJ's evaluation builds on a question in the European Survey that only asks whether legal aid concerns criminal, civil, or other matters (CEPEJ EVAL 2014, Q.20, p. 488). It does not ask how extensive the aid is - for example, whether all criminal cases are covered, or only the most serious ones. As shown in the citation above, the report therefore admits that the problem coverage in civil cases varies significantly. Such exclusions will usually be made by removing certain types of problem, as we have seen in Norway, Ireland (Airy), and England (Steel and Morris) and might well conflict with the case law of the ECtHR.

The report does, however, rank the European schemes in four groups of generosity, using the number of cases and spending per case as criteria. Norway, and to a lesser extent, the Netherlands and Ireland belong to the top group with the most generous schemes, while Finland is placed in the second group. ${ }^{11}$

As shown in the comparison of Norway with Finland, spending appears to be an unreliable predictor of actual coverage. Taking into account the quite complex Airy criteria described above, I think it more 
to the point to conclude that, in most areas, the Finnish scheme is significantly more generous than its Norwegian counterpart. The obvious exception is the few case categories in the Norwegian scheme where everyone has free access to legal assistance both outside the courts and in court cases.

\section{Conclusion}

Although Finland and Norway both use welfare ideology to legitimate their legal aid schemes, the analysis shows significant differences. Finland uses universal problem criteria, while Norway is selective, focusing on a limited selection of legal problems regarded as being statistically the most detrimental to people's welfare. Both countries exclude the most affluent part of the population from coverage and require contributions, although Norway excludes from means testing a small selection of problems relating to loss of freedom due to governmental intervention, and harm due to the criminal acts of other citizens.

None of the schemes cover all costs. If a legal aid grantee loses his case and the court order him to pay the opposing party's cost, they are not covered by any of the schemes, which might make the full cost risk difficult to predict and deter poor people from going to court even when they qualify for legal aid.

Delivery is most efficient in Finland, due to the extensive network of public law offices and their central role in managing the legal aid system. Norway's civil scheme lacks efficient mechanisms to check if the available judicare capacity is sufficient for most case categories. For efficiency reasons, Norway allows the judicare lawyer in question to grant up to 10 hours of aid. Those decisions are made on the basis of the capacity and interests of the individual lawyer. They cannot ensure a rational overall use of the available capacity for legal aid, and may be a significant cost driver. The Norwegian system probably makes strict, mechanical rules on entitlement to legal aid a necessity. Finland's legal aid policy appears more holistic than Norway's since it puts more emphasis on integration and coordination of the different sectors and suppliers (Johnsen 2008, pp. 94-99; Johnsen 2009, pp. 19-21). 
Both Finland and Norway have developed schemes for legal assistance for non-court problems. Welfare ideology is a major motivation. Establishing welfare states has meant a variety of new rights and obligations, and also new bureaucracies that must function properly to fulfil governments' obligations. Legal aid is also important in dealing directly with malfunctions in public administration without going to court.

Non-LAA schemes provide a major share of the total supply of noncommercial legal services in both Finland and Norway. They cover a far larger volume of service needs than the general legal aid schemes and both countries allocate significant public funds to them. I would expect third sector schemes to be important in other European countries too.

The existence of a large third sector in both countries is also an important indicator that governmental non-court advice schemes are seriously inadequate, although there is no reliable mapping. Finland is aware of the challenge and has developed a countrywide telephone service from the public law offices.

Since human rights are meant to be effective for everyone, empirical analyses are important for a reliable picture. However, such comparisons are almost impossible today, due both to the complexity of the issue and the lack of research. Only rough and uncertain assumptions can be made.

The data on European legal aid schemes gathered by the CEPEJ are rough and basic. Although the scope for error is considerable, one cannot escape the assumption that the enormous variation in legal aid funding among European countries also means that the legal aid offered to the poorer part of the population differs significantly both in volume and quality.

Nordic legal aid schemes seem better developed than those of most other European countries. Finland's legal aid is more universal overall, and makes significantly more use of public delivery than Norway. From a European perspective both these features are unique.

Together with the English-speaking countries, the Netherlands, and Switzerland, the Nordic countries seem to constitute the top fourth of European schemes when it comes to coverage, while countries in Southern and Eastern Europe spend significantly less. On the other hand, we do not find similar differences in spending on courts. Data are, however, quite rudimentary. 
One possible theory is that differences in legal cultures explain some of the findings. Common law countries have traditionally favoured adversarial proceedings, while Roman law countries have relied on the inquisitorial method. A fair adversarial proceeding demands significantly more input from the parties than systems that put the judge in charge of collecting and analysing the evidence. Efficient legal aid schemes seem far more crucial to adversarial proceedings than to inquisitorial schemes if trials are to be fair. However, further research is needed to draw conclusions.

Are welfare ideology and access to justice competing ideologies for legitimating legal aid schemes? Welfare ideology focuses on the structure of people's needs, problems, and well-being, and asks how legal expertise can best contribute to solving them. The access to justice perspective is mainly concerned with people's right and capacity to use a specific institution—namely the courts—-for problem solving, and puts less emphasis on whether the courts can provide them with viable solutions to their problems in an efficient way. In a nutshell: welfare ideology takes an instrumental approach, while access to justice is institutional. The welfare meaning of access to justice therefore depends on the substantive content of people's rights, and the existence of non-implemented rights that can be made operational through better access to the courts.

The poorer states in Europe prioritise criminal legal aid over civil aid. Although fines and prison sentences obviously impact negatively on people's welfare, such protection is not at the heart of welfare ideology. Welfare rights are meant to improve the quality of people's lives, not to protect them from unreasonable punishment by the state. Welfare states have so far seemed more inclined to view legal aid and advice outside court as a better method to impact welfare bureaucracies than putting pressure on them through the courts. 'Access to justice', as expressed in the human rights doctrine, has the potential to become a driver for progressive change in the Nordic schemes, as well as in other European schemes. The case law of the ECtHR contains important decisions on legal aid and is an obvious driver for the reform of legal aid in Europe. Finland and Norway, for example, have incorporated the access to justice provisions in human rights treaties into their constitutions. However, closer analysis reveals that the implementation in national law has flaws that might need correction. 
It is highly likely that, in the European countries with the poorest funding, we will find widespread violations of the Article 6 entitlement to legal aid, which demonstrates that the human rights obligations of many European states demand reforms in their legal aid schemes. CEPEJ also lists a number of legal aid reforms in progress in the member states (CEPEJ EVAL 2014, p. 89).

The mandate of the CEPEJ still has the potential to ensure more effort is put into improving European legal aid. The ECtHR has repeatedly stated that 'Article 6 (1) of the Convention imposes on the Contracting States the duty to organize their judicial systems so that they can meet its requirements.' Member states have the freedom to choose different strategies to fulfil their obligations to develop access to justice. They could consider the option of providing legal aid by reorganising the judicial system in a way that diminishes the need for legal assistance. They could simplify both substantive and adjudicative law, and better educate citizens in legal matters, or develop 'doit-yourself'-systems that might diminish the need for professional legal counselling and representation. Many matters might be resolved faster and more inexpensively through ADR. Such strategies might become options for governments to improve their legal aid schemes. At all events states must act, and the outcomes must satisfy their human rights obligations.

\section{Notes}

1. Johnsen 2008 builds on two national research projects. The Norwegian research was conducted by Statskonsult and published in Statskonsult 2008. The Finnish study was carried out by the National Research Institute of Legal Policy (OPTULA). It was published in Henriikka Rostii \& Johanna Niemi \& Marjukka Lasola 2008. Additional materials were used when substantiated, see: Regan \& Johnsen, Jon T. 2007 and Johnsen \& Regan 2008. Both the Norwegian and the Finnish Ministry of Justice supported the project and, upon request, they provided the comparative research project with all data and materials that they possessed.

2. Norway: rettshjelpsloven 1980, straffeprosessloven 1981, Finland: Rättshjälpslag 2002, Lag om statliga rättshjälpsbyråer 2002, and Lag om rättegång i brottmål 1997. Finnish legislation is issued in both in Finnish 
and Swedish. I read Swedish, but not Finnish, and therefore use the Swedish versions for references and citations.

3. Both Finland and Norway exclude problems covered by legal expense insurance from legal aid.

4. My comparison builds upon the public documents establishing the present LAA schemes

5. See http://search.un.org/original/?tpl=un\&search_group=untc\&lang=e n\&query=CCPR. Visited 20 March 2016. 179 nations had joined CCPR. (181 if Scotland and Northern Ireland are counted separately as in the CEPEJ statistics.)

6. Usually labelled 'margin of appreciation'.

7. See, for example, Hadjinis v Greece (Judgment of 28 April 2005).

8. The UN Human Rights Committee, in a communication concerning CCPR article 14, said that Norwegian Sami seeking court protection for their reindeer herding rights, and risking the high costs of the opposing party, might qualify for legal aid (Joseph and Schultz 2004, pp. 397-398. They refer to $1991 \mathrm{UN}$ doc. CCPR/C/79/Add 112). The Committee expressed a similar opinion in a communication concerning Finnish Sami seeking court protection for their rights according to CCPR article 27. A strict obligation to pay the opponent's costs if they lost the case, with no discretionary power for the court to modify it, might deter them from accessing the court and violate CCPR article 14 (Joseph and Schultz 2004, pp.398-399 (Ä̈̈relä and Näkkäläjärviv Finland Communications 779/97)).

9. CEPEJ EVAL 2014 gives separate statistics for the three UK jurisdictions England and Wales, Northern Ireland, and Scotland

10. 17 states did not give any figures on the number of applications granted.

11. The other Nordic schemes have not been ranked in the CEPEJ report, doubtless because of lack of data.

\section{References}

Berg, O. T., \& Christensen, J. (2014). Velferdsstat. In Store norske leksikon. Collected 12 March 2016 from https://snl.no/velferdsstat

Francioni, F. (2007). The rights of access to justice under customary international law. In F. Francioni (Ed.), Access to justice as a human right (pp. 1-56). Oxford: Oxford University Press.

Johnsen, J. T. (1994). Nordic legal aid. Maryland Journal of Contemporary Legal Issues, 5(2), 301-331. 
Johnsen, J. T. (2006). How has the complexity of the law and the market for legal expertise impacted on the development of legal aid in Norway? International Journal of the Legal Profession, 13(1), 19-39.

Johnsen, J. T. (2008). Hva kan vi lare av finsk rettshjelp? En sammenlikning av rettshjelpordningene i Norge og Finland. Oslo: Justis- og politidepartementet 2009. Appendix to St.meld 26 (2008-2009) Om offentleg rettshjelp. Rett til hjelp. Justisdepartementet.

Johnsen, J. T. (2009). Might Norway learn from Finnish legal aid? A comparison of legal aid in Norway and Finland. Summary Report from Johnsen 2008. Paper to "Delivering Effective Legal Aid Services Across Diverse Communities" ILAG Conference Wellington New Zealand 2009-04-01-2009-04-03.

Johnsen, J. T., \& Regan, F. (2008). How to use an international "best policy"model in the analysis and improvement of Finnish legal aid. In C. H. van Rhee \& A. Uzelac (Eds.), Civil justice between efficiency and quality: From Ius commune to the CEPEJ (pp. 151-188). Intersentia: Antwerp-Oxford-Portland.

Joseph, S., \& Schultz, J. (2004). The international covenant on civil and political rights. Oxford: Oxford University Press.

Litmala, M. (2006). Evaluating the practical effects of the Finnish reform of legal aid. 6th International LSRC Conference 2006, pp. 166-88.

Regan, F., \& Johnsen, J. T. (2007). Are Finland's recent legal services policy reforms swimming against the tide of international reforms? Civil Justice Quarterly, 26, 341-357.

Rostii, H., Niemi, J., \& Lasola, M. (2008). Legal Aid and Services in Finland. National Research Institute of Legal Policy Report 237.

Statskonsult 2008 Kartlegging av rådgivnings- og konfliktløsningstilbudet i Norge DIFI-report 2008:1.

\section{Legislation and Other Legislative Documents}

\section{Finland:}

Rättshjälpslag 5.4.2002/257 (FLAA).

Lag om statliga rättshjälpsbyråer 5.4.2002/258.

Lag om rättegång i brottmål 11.7.1997/689 (FCPC).

Regeringens proposition till Riksdagen med förslag till rättshjälpslag och vissa lagar som har samband med den, RP 82/2001 rd, p. 5. 


\section{Norway:}

Lov 13. juni $1980 \mathrm{nr} 35$ om fri rettshjelp (NLAA).

Lov 22. mai $1981 \mathrm{nr} 25$ om rettergangsmåten i straffesaker (NCPC).

Lov 21.mai 1999 nr.30 om styrking av menneskerettighetenes stilling i norsk rett (Menneskerettsloven).

Ot. Prp. 35(1979-80).

St.meld. nr. 25 (1999-2000) Om fri rettshjelp.

St.meld. nr. 26 (2008-2009) Om offentleg rettshjelp. Rett til hjelp.

\section{Council of Europe/CEPEJ:}

Convention for the Protection of Human Rights and Fundamental Freedoms (ECHR)

European Commission for the Efficiency of Justice 2014 European judicial systems. Efficiency and quality of justice. Edition 2014 (2012 data). CEPEJ. Council of Europe. Strasbourg (CEPEJ EVAL 2014).

Resolution 76 (5) on legal aid in civil, commercial and administrative matters. Adopted by the committee of ministers on 18 February 1976 at the 254th meeting of the Ministers' deputies. Council of Europe. European commission for the efficiency of Justice Relevant Council of Europe Resolutions and Recommendations in the field of efficiency and fairness of justice. CEPEJ 20037 Rev. 5.

Resolution 78 (8) on legal aid and advice. Adopted by the committee of ministers on 2 March 1978 at the 284th meeting of the Ministers' deputies. Council of Europe. European Commission for the efficiency of Justice Relevant Council of Europe Resolutions and Recommendations in the field of efficiency and fairness of justice. CEPEJ (2003) 7 Rev 6-8.

Recommendation No R (93) 1 on effective access to the law and to justice for the very poor. Adopted by the committee of ministers on 8 January 1993 at the 484th meeting of the Ministers' deputies. Council of Europe. European Commission for the efficiency of Justice Relevant Council of Europe Resolutions and Recommendations in the field of efficiency and fairness of justice. CEPEJ (2003) 7 Rev. pp. 27-29.

Recommendation (2000) 21 on the freedom of exercise of the profession of lawyers. Adopted by the Committee of Ministers on 25 October 2000 at the 727th Meeting of the Ministers' Deputies. 
Recommendation (2001) 3 on the delivery of court and other legal services to the citizen through the use of new technologies. Adopted by the committee of ministers on 28 February 2001 at the 743th meeting of the Ministers' deputies. Council of Europe. European Commission for the efficiency of Justice Relevant Council of Europe Resolutions and Recommendations in the field of efficiency and fairness of justice. CEPEJ (2003) 7 Rev. pp. 84-89. Resolution (Res. (2002)12) establishing the European Commission for the efficiency of justice (CEPEJ). Adopted by the committee of ministers on 18 September 2002 at the 808th meeting of the Ministers' deputies and amended on 19 March at the 832nd meeting of the Ministers' deputies. Council of Europe. CEPEJ/GENERAL (2003) p. 1.

United Nations Intenternational Convention of Civil and Political Rights (CCPR)

Open Access This chapter is distributed under the terms of the Creative Commons Attribution 4.0 International License (http://creativecommons.org/ licenses/by/4.0/), which permits use, duplication, adaptation, distribution, and reproduction in any medium or format, as long as you give appropriate credit to the original author(s) and the source, a link is provided to the Creative Commons license, and any changes made are indicated.

The images or other third party material in this book are included in the work's Creative Commons license, unless indicated otherwise in the credit line; if such material is not included in the work's Creative Commons license and the respective action is not permitted by statutory regulation, users will need to obtain permission from the license holder to duplicate, adapt or reproduce the material.

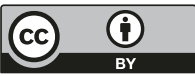

